\title{
Exploration of 'hot-spots' of methane and nitrous oxide emission from the agriculture fields of Assam, India
}

Satyendra Nath Mishra ${ }^{1 \dagger}$, Sudip Mitra ${ }^{2^{*}}$, Latha Rangan ${ }^{3}$, Subashisha Dutta ${ }^{3}$ and Pooja Singh ${ }^{2}$

\begin{abstract}
Background: Agricultural soils contribute towards the emission of $\mathrm{CH}_{4}$ (mainly from paddy fields) and $\mathrm{N}_{2} \mathrm{O}$ (from $\mathrm{N}$-fertilizer application), the two important greenhouse gases causing global warming. Most studies had developed the inventories of $\mathrm{CH}_{4}$ and $\mathrm{N}_{2} \mathrm{O}$ emission at the country level (larger scale) for India, but not many studies are available at the local scale (e.g. district level) on these greenhouse gases (GHGs). Assam is an important state in the North Eastern region of India. In addition to being the regional economic hub for the entire region, agriculture is the major contributor to the state's gross domestic product. In Assam about three-fourths of the area is under paddy cultivation and rice is the staple food. With this background, a district wise inventory of $\mathrm{CH}_{4}$ and $\mathrm{N}_{2} \mathrm{O}$ emission in the North Eastern state of Assam, India was carried out using different emission factors, viz., IPCC, Indian factors and others, to highlight the discrepancies that arose in the emission estimation of these important GHGs while used at the smaller scale i.e. district level. This study emphasizes the need for better methodologies at the local level for GHGs inventories. This study also reiterates the fact that no emission factor is universally applicable across all regions. The GHGs like $\mathrm{CH}_{4}$ and $\mathrm{N}_{2} \mathrm{O}$ are highly site and crop specific and the factors required for their inventory are driven by cultural practices, agronomic management, soil resources and socio-economic drivers.

Material and methods: In this study, Intergovernmental Panel on Climate Change (IPCC) methodology was used for the estimation of $\mathrm{CH}_{4}$ and $\mathrm{N}_{2} \mathrm{O}$ emission. In case of $\mathrm{N}_{2} \mathrm{O}$ emission, both direct and indirect emission from agricultural soil was estimated for the various districts of Assam.

Results: The $\mathrm{CH}_{4}$ (base year 2000-2001) and $\mathrm{N}_{2} \mathrm{O}$ (base year 2001-2002) emission was estimated to be $121 \mathrm{Gg}$ and $1.36 \mathrm{Gg}$ from rice paddy and agricultural fields of Assam state respectively.

Conclusions: This study is the first report on the estimation of the GHG emission at the district level from the entire state of Assam, agriculturally one very important state of North Eastern India. This state is also considered as remote due to its geographical location. The study clearly elucidates that there is large variation in the emission inventory of $\mathrm{CH}_{4}$ and $\mathrm{N}_{2} \mathrm{O}$ at the district level (local scale) when different emission factors are used. This calls for detailed and comprehensive data collection and mapping at the micro level for accurate inventory of greenhouse gases in future from agriculture fields.
\end{abstract}

Keywords: Agriculture, Paddy fields, Methane, Nitrous oxide, Assam, India

\footnotetext{
* Correspondence: sudipmitra@yahoo.com

${ }^{\dagger}$ Equal contributors

${ }^{2}$ School of Environmental Sciences, Jawaharlal Nehru University, New Delhi

110067, India

Full list of author information is available at the end of the article
} 


\section{Background}

Increasing industrialisation and developmental activities across the globe have led to stress on the Earth's resources. One of the major damaging impacts of this increasing developmental activity (especially industrial and agricultural) is increasing concentration of the greenhouse gases (GHGs), namely, carbon dioxide $\left(\mathrm{CO}_{2}\right)$, methane $\left(\mathrm{CH}_{4}\right)$, nitrous oxide $\left(\mathrm{N}_{2} \mathrm{O}\right)$, chlorofluorocarbon (CFCs), etcetera, which are potential causes of global warming due to the enhanced greenhouse effect. $\mathrm{CO}_{2}, \mathrm{CH}_{4}$ and $\mathrm{N}_{2} \mathrm{O}$ are key GHGs that contribute toward global warming at $60 \%, 15 \%$ and $5 \%$ respectively $[1,2]$. Concentrations of these gases in the atmosphere are increasing at $0.4 \%, 0.3 \%$ and $0.22 \%$ per year respectively $[1,3]$. On average, the agricultural sector emits about $47 \%$ and $58 \%$ of total global anthropogenic emissions of $\mathrm{CH}_{4}$ and $\mathrm{N}_{2} \mathrm{O}$ respectively. Although $\mathrm{CH}_{4}$ and $\mathrm{N}_{2} \mathrm{O}$ emission constitutes only about $20 \%$ of the total GHG emissions, they play a significant role in global warming due to their higher values of global warming potential (GWP) of 21 and 310 respectively. It has been estimated that about $74 \%$ of the agricultural GHG emissions are from non-annex ${ }^{1}$ countries [4]. The amount of $\mathrm{CH}_{4}$ emission from paddy fields (about 50 to100 $\mathrm{Tg} \mathrm{yr}^{-1}$ ) accounts for about $10 \%$ to $20 \%$ of total $\mathrm{CH}_{4}$ emission around the world. Huang et al. [5] projected that the $\mathrm{CH}_{4}$ emission from rice fields may increase to $145 \mathrm{Tg} \mathrm{yr}^{-1}$ by 2025. Industrial nitrogen fixation for use in agriculture had increased from less than $10 \mathrm{Tg} \mathrm{yr}^{-1}$ in the 1950s to over $80 \mathrm{Tg} \mathrm{yr}^{-1}$ by the year 2000. Nitrogen applied in agricultural systems is emitted in different forms like dinitrogen, ammonium, dissolved organic nitrogen or $\mathrm{NO}_{\mathrm{x}}$. Of all these $\mathrm{N}_{2} \mathrm{O}$, which is increasing in the atmosphere at the rate $0.2 \%$ to $0.3 \%$ per year, is of particular concern [6].

The anthropogenic emission of $\mathrm{CO}_{2}, \mathrm{CH}_{4}$ and $\mathrm{N}_{2} \mathrm{O}$ in India was about 1,398,700 Gg, 20,560 Gg and $240 \mathrm{Gg}$ respectively in the year 2007 [7]. In 2007, the agriculture sector was the largest source of $\mathrm{CH}_{4}$ emission, accounting for about $65 \%$ of the total. Of this, livestock, paddy cultivation and onsite burning of crop residues represented shares of $48 \%, 16 \%$ and $1 \%$ respectively. In view of this, Indian scientists have placed special emphasis in recent times on the exploration of $\mathrm{CH}_{4}$ emission from paddy fields [8-12]. In 2007, the agricultural sector accounted for about $65 \%$ of total $\mathrm{N}_{2} \mathrm{O}$ emission in India. The main source of direct and indirect $\mathrm{N}_{2} \mathrm{O}$ emission in agriculture was the application of nitrogen fertilizer ${ }^{2}$ [7]. In 2008, the Government of India (GoI) came up with the National Action Plan on Climate Change. Of the eight national missions mentioned in this plan, one deals with a national mission for sustainable agriculture [13]. After the energy sector, being a dominant and dynamic source of GHG emission, the agricultural sector got special attention for studies and management to abate GHG emissions [14]. It has been easy to change the technology to reduce GHG emission from the energy sector either by using regulatory norms or good backstop technology. However, this is not the case with the agricultural sector, as agriculture directly deals with the cultural, socioeconomic matrix of society and farmers, and local setup. So, it is not easy to assess the emissions, due to the random distribution of variables on which emissions depend, or to develop a proper mitigation plan at field level. Few studies have been taken at experimental level to estimate GHG emissions at the local level $[15,16]$.

National level data provides lots of information and inputs for national and international level planning and negotiation. However, data and information at district level would be imperative and very important in the near future for local level decision-making, and for upcoming district and regional planning activities initiated at local and regional level in the age of the decentralised planning approach. It is unanimously accepted across the scientific and policy-making bodies that while climate change and global warming is a global phenomenon, its solution lies at the level of local planning and adaptation. Considering this background, a local level study was carried out by estimating district-wise emission of $\mathrm{CH}_{4}$ and $\mathrm{N}_{2} \mathrm{O}$ from rice paddy and agricultural fields respectively for the state of Assam, India, as per the Intergovernmental Panel on Climate Change (IPCC) guidelines and using other available emission factors ${ }^{3}$. Assam is the gateway to the north-eastern part of India, situated between $90^{\circ}$ to $96^{\circ}$ longitude east and $24^{\circ}$ to $28^{\circ}$ latitude north. Assam is bordered in the north and east by the Kingdom of Bhutan and Arunachal Pradesh state. The states, namely, Nagaland, Manipur and Mizoram are situated in the South of Assam, and West Bengal state and Bangladesh to the west. Meghalaya state lies to the south-west of Assam.

\section{Material and methods}

Extensive data collection and investigation was carried out to make the inventory of $\mathrm{CH}_{4}$ and $\mathrm{N}_{2} \mathrm{O}$ emissions at the district ${ }^{4}$ level (smaller administrative unit) in one of the major paddy-growing states of India, namely, Assam in the north-eastern part of India. Assam was chosen for this study as paddy is the major crop in this state, is grown three times a year, and is major source of agricultural gross domestic product (GDP) ${ }^{5}$. Emission of $\mathrm{CH}_{4}$ from paddy fields and $\mathrm{N}_{2} \mathrm{O}$ from agricultural fields (as per the Indian emission factor and IPCC standard) were represented geographically on the map of Assam using Geomatica GIS software.

\section{Data collection}

The $\mathrm{CH}_{4}$ emission inventory from the paddy fields of all the districts of Assam was calculated by taking into 
consideration that the paddy area was under the high yielding variety(HYV). Information about paddy fields under different water management systems was obtained from the Statistical Handbook of Assam 2003 [17]. District-wise irrigation potential utilized in Assam during the Kharif, Rabi, and pre-Kharif seasons in 2000 to 2001 was taken as the paddy field area under a continuous irrigation system. Paddy is the major crop in Assam, is grown in all three seasons of the year, and demands a huge amount of water. It was assumed that all the irrigation potentials were used only for the paddy cultivation. Information about the district-wise area under a rain-fed ecosystem was obtained by subtracting the area under HYV of paddy for the year 2000 to 2001, with that of the area under continuous irrigation. Emission factors for these water management practices were followed as per the IPCC report.

Estimation of $\mathrm{N}_{2} \mathrm{O}$ emission from agricultural fields was done using the district-wise data of $\mathrm{N}$-fertilizer use in the year 2001 to 2002 [17]. $\mathrm{N}_{2} \mathrm{O}$ emission due to animal manure was calculated using livestock data from the 1997 livestock census [17]. During calculation, two factors that affect direct $\mathrm{N}_{2} \mathrm{O}$ emission are not taken into consideration due to non-availability of data, namely, $\mathrm{N}_{2} \mathrm{O}$ emission due to the $\mathrm{N}$ - fixed by the crops biologically and the amount of emission contributed by the burning of $\mathrm{N}$-fixing and non- $\mathrm{N}$ fixing crop residue in the State (Tables 1 and 2). The choice of different base years for $\mathrm{CH}_{4}$ and $\mathrm{N}_{2} \mathrm{O}$ was made on the basis of data availability at that point of time when the study was conducted. Multiple years of data may provide better accuracy in the inventory. Considering the fact that this study is the first attempt towards a district-level inventory of the Assam state, even one year of data provides a reasonable idea about the GHG emission potentials at the district level and the importance of developing site-specific emission factors.

\section{Methodology for the emission inventory Methane}

The district-wise inventory of $\mathrm{CH}_{4}$ emission from Assam was calculated on the basis of the IPCC formula that was issued in the revised guideline in 1996 [19]. Also three different emission factors were used to estimate the $\mathrm{CH}_{4}$ emission from the districts of Assam. This was to highlight the differences in the $\mathrm{CH}_{4}$ emission and the need for a proper local-level emission inventory database for better planning and mitigation strategies in the future. The details of the four different factors that were used are as follows.

\section{Emission factor as reported by Gupta et al}

The seasonal integrated flux of $46 \mathrm{~g} \mathrm{~m}^{-2}$ was used for the calculation of $\mathrm{CH}_{4}$ emission in this case. This emission flux was from the Jorhat experimental farms in which the HYV Mahsuri cultivar of paddy was grown in the year 1991. The seasonal integrated flux was much higher than the other experimental stations in India due to the irrigated water regime, addition of organic amendment in the experimental field [32], and higher content of organic carbon in the soil of North Eastern states (about 5\%) of India (about 1\%) [8].

\section{IPCC emission factor based on Bhatia et al}

The IPCC emission factor for the base year 1994 to 1995 was calculated by dividing the methane emission of Assam as calculated in the study reported by Bhatia et al. using the IPCC emission factor. The emission factor was calculated as follows:

Emission factor in $\mathrm{g} \mathrm{m}^{-2}=$ total emission from paddy field of Assam [8]/total area under paddy cultivation [17] = the factor comes out to be $12.81 \mathrm{~g} \mathrm{~m}^{-2}$.

\section{Indian emission factor based on Bhatia et al}

The Indian emission factor for base year 1994 to 1995 was calculated by dividing the methane emission of Assam as calculated by Bhatia et al. using the Indian emission factor.

Emission factor in $\mathrm{g} \mathrm{m}^{-2}=$ total emission from paddy field of Assam [8]/total area under paddy cultivation [17] $=$ the factor comes out to be $6.92 \mathrm{~g} \mathrm{~m}^{-2}$.

\section{Emission factor used for this study as per the IPCC standard equation}

The emission factor and details used in this study for calculation of district-wise $\mathrm{CH}_{4}$ emission for Assam was as per the IPCC formula. The assumptions made in the calculation of $\mathrm{CH}_{4}$ emission were as follows: 1) paddy field irrigated under continuous flooding was taken based on the district-wise irrigation potential for the Kharif, Rabi, and pre-Kharif seasons in the year 2000 to 2001 [17]. Paddy is the major crop and is cultivated three times a year, so it was assumed that most of the irrigation was used for it; 2) paddy field under a rain-fed, flood-prone condition was obtained by subtracting the area under continuous flooding from the total area under paddy cultivation (HYV variety) for each district [17]. The formula used for the calculation of $\mathrm{CH}_{4}$ emission as per the IPCC guideline [19] is as follows:

$$
\operatorname{Emission}\left(\operatorname{Tgyr}^{-1}\right)=\Sigma_{i} \Sigma_{j} E F_{i j} * 10^{-12}
$$

where $\mathrm{i}=$ irrigation under continuous flooding system, $\mathrm{j}=$ rain-fed flood-prone, $\mathrm{EF}_{\mathrm{j}}$ (seasonally integrated emission factor for rain-fed flood-prone) $=8 \mathrm{~g} \mathrm{~m}^{-2}$, and $E F_{i}$ (seasonally integrated emission factor for irrigation under continuous flooding) $=10 \mathrm{~g} \mathrm{~m}^{-2}$ [8]. 
Table 1 Details of factors used for the assessment of direct nitrous oxide $\left(\mathrm{N}_{2} \mathrm{O}\right)$ emission

\begin{tabular}{|c|c|c|c|c|c|}
\hline \multirow[t]{2}{*}{ Primary factor } & \multirow{2}{*}{$\begin{array}{l}\text { Break-up of } \\
\text { primary factor }\end{array}$} & \multirow[t]{2}{*}{ Details } & \multicolumn{2}{|l|}{ Coefficient or value } & \multirow[t]{2}{*}{ Remark } \\
\hline & & & IPCC emission factor & Indian emission factor & \\
\hline \multirow{2}{*}{$\begin{array}{l}\text { FN (annual amount of synthetic } \\
\mathrm{N} \text {-fertilizer applied to soil adjusted } \\
\text { for the amount that volatilizes as } \\
\mathrm{NH}_{3} \text { and } \mathrm{NO}_{x} \text { ) }\end{array}$} & $\mathrm{N}_{\text {FERT }}$ & $\begin{array}{l}\text { The total amount of synthetic } \\
\text { fertilizer consumed annually [18] }\end{array}$ & - & - & - \\
\hline & $\mathrm{F}_{\mathrm{racGASF}}$ & $\begin{array}{l}\text { Fraction of fertilizer volatilize as } \\
\mathrm{NH}_{3} \text { and } \mathrm{NO}_{x}\end{array}$ & $10.0 \%[19]$ & $15.0 \%[8,20]$ & $\begin{array}{l}\text { The difference in the emission factor was due } \\
\text { to soil management practices, soil type, pH, } \\
\text { climatic condition and also the methodology } \\
\text { used for emission assessment [19]. Details of } \\
\text { differences in the emission factor due to } \\
\text { different methodology used for assessment } \\
\text { have been discussed in the Sarkar study [20]. }\end{array}$ \\
\hline \multirow[t]{9}{*}{$\begin{array}{l}\mathrm{F}_{\text {AM }} \text { (annual amount of animal } \\
\text { manure nitrogen applied to } \\
\text { soils adjusted to account for } \\
\text { volatilization of } \mathrm{NH}_{3} \text { and } \mathrm{NO}_{x} \text { ) }\end{array}$} & $T$ & Each defined livestock & - & - & $\begin{array}{l}\text { For this study four categories were taken, } \\
\text { namely, cattle, buffalo, sheep and goat, based } \\
\text { on the details available in the Assam statistical } \\
\text { handbook [17]. }\end{array}$ \\
\hline & $\mathrm{N}_{(\mathrm{T})}$ & $\begin{array}{l}\text { Number of animals in each } \\
\text { category [17] }\end{array}$ & - & - & - \\
\hline & $N_{e x}(T)$ & $\begin{array}{l}\text { Annual average nitrogen } \\
\text { excretion rate per head for each } \\
\text { livestock }\end{array}$ & $\begin{array}{l}\text { Recommended to use } \\
\text { country specific factors [19] }\end{array}$ & $\begin{array}{l}\text { Indian emission factor } \\
\text { for each livestock } \\
\text { category [21] }\end{array}$ & $\begin{array}{l}N_{\text {ex (T) }} \text { in } \mathrm{g} \mathrm{yr}^{-1}=(\text { wet dung excreted by } \\
\left.\text { livestock in } \mathrm{g} \text { day })^{-1}\right)^{*}(\text { dry matter of livestock)* } \\
\text { (nitrogen constant of livestock)*365 }\end{array}$ \\
\hline & Frac $_{\text {GASM }}$ & $\begin{array}{l}\text { Fraction of } \mathrm{N} \text { that volatilizes in } \\
\mathrm{NH}_{3} \text { and } \mathrm{NOx}\end{array}$ & $20.0 \%[19]$ & $15.0 \%[8]$ & - \\
\hline & Frac Fuel $_{\text {f }}$ & Animal manure burnt for fuel & $52.5 \%[22]$ & $52.5 \%[22]$ & $\begin{array}{l}\text { IPCC manual suggested to national study or } \\
\text { official statistics of country or region [19] }\end{array}$ \\
\hline & FraC $_{\text {PRP }}$ & $\begin{array}{l}\text { Fraction of animal manure } \\
\text { deposited on soil by grazing } \\
\text { livestock }\end{array}$ & Not used in this study & Not used in this study & No data were available \\
\hline & FracCOLLEC & $\begin{array}{l}\text { Loss during the collection of } \\
\text { dung }\end{array}$ & $30.0 \%[23]$ & $30.0 \%[23]$ & - \\
\hline & $\mathrm{F}_{\text {racFEED }}$ & $\begin{array}{l}\text { Fraction of animal manure used } \\
\text { as feed }\end{array}$ & $0.0 \%$ & $0.0 \%$ & $\begin{array}{l}\text { Taken as zero, as animal manure is hardly } \\
\text { used as feed in India [8] }\end{array}$ \\
\hline & $\overline{F_{\text {racCONST }}}$ & $\begin{array}{l}\text { Fraction of animal manure used } \\
\text { in construction }\end{array}$ & $2.0 \%[22]$ & $2.0 \%[22]$ & - \\
\hline \multirow[t]{2}{*}{$\begin{array}{l}F_{B N} \text { (amount of nitrogen fixed } \\
\text { annually by nitrogen fixing crops) }\end{array}$} & Crop $_{B F}$ & $\begin{array}{l}\text { Seed yield of nitrogen fixing } \\
\text { crops }\end{array}$ & Not used in this study & Not used in this study & \multirow[b]{2}{*}{$\begin{array}{l}\text { If seen in terms of area under nitrogen fixing } \\
\text { crop in Assam (about } 1.23 \text { lakh hectare was } \\
\text { under pulses in } 2000 \text { to } 2001 \text {, against gross } \\
\text { cropped area of } 38.43 \text { lakh hectares) then } F_{B N} \\
\text { contribution to total } \mathrm{N}_{2} \mathrm{O} \text { emission may be } \\
\text { negligible [17]. However, it is imperative that } \\
\text { to have comprehensive source and sink of } \\
\text { GHG emission from agriculture sector, which } \\
\text { would help in developing better mitigation } \\
\text { strategy and policy in the future. This study } \\
\text { could not estimate the emission of } \mathrm{F}_{B N} \text {, due } \\
\text { to non-availability of data at district level. }\end{array}$} \\
\hline & FraC $_{N C R B}$ & $\begin{array}{l}\text { Nitrogen content of grain and } \\
\text { straw of legumes }\end{array}$ & Not used in this study & Not used in this study & \\
\hline
\end{tabular}


Table 1 Details of factors used for the assessment of direct nitrous oxide $\left(\mathbf{N}_{\mathbf{2}} \mathbf{O}\right)$ emission (Continued)

\begin{tabular}{|c|c|c|c|c|c|}
\hline \multirow[t]{4}{*}{$\begin{array}{l}\mathrm{F}_{\mathrm{CR}} \text { (amount of nitrogen in crop } \\
\text { residues returned to soil annually) }\end{array}$} & Cropst $_{\text {ST }}$ & $\begin{array}{l}\text { Amount of straw of non-nitrogen } \\
\text { fixing crops incorporated to the } \\
\text { soil as residue }\end{array}$ & Not used in this study & Not used in this study & \\
\hline & $\mathrm{Frac}_{\text {NCRST }}$ & $\begin{array}{l}\text { Nitrogen content of residue of } \\
\text { non-nitrogen fixing crops }\end{array}$ & Not used in this study & Not used in this study & \\
\hline & Crop $_{\mathrm{SBF}}$ & $\begin{array}{l}\text { Amount of straw of nitrogen } \\
\text { fixing crops incorporated to the } \\
\text { soil as residue }\end{array}$ & Not used in this study & Not used in this study & \multirow{2}{*}{$\begin{array}{l}\text { The gross cropped area in Assam - other than } \\
\text { paddy and pulses -under spices, horticulture, } \\
\text { vegetable, wheat etcetera, was about } 12.74 \\
\text { lakh hectares in } 2000 \text { to } 2001 \text { [24]. Since crop } \\
\text { residue in India is mostly used as fodder or as } \\
\text { burning fuel, it is likely that the contribution } \\
\text { to } \mathrm{N}_{2} \mathrm{O} \text { emission would not be substantial. } \\
\text { However, it is always warranted that if data } \\
\text { are made available, the emission inventory } \\
\text { would have to be developed in the future. }\end{array}$} \\
\hline & $\mathrm{FraC}_{\text {NCRSBF }}$ & $\begin{array}{l}\text { Nitrogen content of residue of } \\
\text { nitrogen fixing crops }\end{array}$ & Not used in this study & Not used in this study & \\
\hline $\mathrm{EF}_{1}$ (kg N $\mathrm{N}_{2} \mathrm{O}-\mathrm{N} \mathrm{kg}^{-1} \mathrm{~N}$ input) & - & $\begin{array}{l}\text { The emission factor for } \mathrm{N}_{2} \mathrm{O}-\mathrm{N} \\
\text { emitted from various nitrogen } \\
\text { additions in soil }\end{array}$ & $0.0125[19]$ & $0.007[8,25,26]$ & $\begin{array}{l}\text { The } \mathrm{N}_{2} \mathrm{O} \text { emission through nitrification and } \\
\text { denitrification in the field, applied with } \\
\text { nitrogen fertilizer are strongly influenced by } \\
\text { soil temperature, moisture, } \mathrm{pH} \text {, and soluble } \\
\text { organic matter availability [27]. It is to be } \\
\text { noted that the IPCC emission factor is taken } \\
\text { from the studies of Klemedtssonet al. [28] } \\
\text { and Clayton et al. [27], as referenced in the } \\
\text { IPCC manual [19]. These studies were done } \\
\text { in Europe's peatland and clay loam grassland } \\
\text { soil respectively. The Indian factor is based } \\
\text { on the studies of Kumaret al. [25], Majumdar } \\
\text { et al. [29] and Pathak et al. [26] which were } \\
\text { done in India. It is to be noted that in } \\
\text { European and Indian conditions the above- } \\
\text { mentioned factors that influence the } \mathrm{N}_{2} \mathrm{O} \\
\text { emission from soil differ markedly, which } \\
\text { led to the differing values of emission } \\
\text { factors. }\end{array}$ \\
\hline $\mathrm{F}_{\mathrm{OS}}$ & - & Area of organic soil harvested & Not used in this study & Not used in this study & $\begin{array}{l}\text { Not an application for Indian conditions, } \\
\text { as the organic content in Indian soil varies } \\
\text { only from } 1 \% \text { to } 5 \% \text {, while organic soils are } \\
\text { those having } 12 \% \text { to } 18 \% \text { organic carbon [8]. }\end{array}$ \\
\hline $\mathrm{EF}_{2}$ & - & $\begin{array}{l}\text { Percent of } \mathrm{N}_{2} \mathrm{O} \text { emissions from } \\
\text { organic soil }\end{array}$ & Not used in this study & Not used in this study & - \\
\hline
\end{tabular}


Table 2 Details of coefficients used for the assessment of indirect nitrous oxide $\left(\mathrm{N}_{2} \mathrm{O}\right)$ emission

\begin{tabular}{|c|c|c|c|c|c|}
\hline \multirow[t]{2}{*}{ Primary factor } & \multirow[t]{2}{*}{ Break-up of primary factor } & \multirow[t]{2}{*}{ Details } & \multicolumn{2}{|l|}{ Coefficient or value } & \multirow[t]{2}{*}{ Remark } \\
\hline & & & IPCC emission factor & Indian emission factor & \\
\hline \multirow{3}{*}{$\begin{array}{l}\mathrm{N}_{2} \mathrm{O}_{(\mathrm{G})}\left(\mathrm{N}_{2} \mathrm{O} \text { emission from }\right. \\
\text { volatilization of applied nitrogen } \\
\text { fertilizer and animal manure and } \\
\text { its subsequent atmospheric } \\
\left.\text { deposition as } \mathrm{NO}_{x} \text { and } \mathrm{NH}_{4}\right)\end{array}$} & $\mathrm{N}_{\mathrm{FERT}}$ & $\begin{array}{l}\text { The total amount of synthetic } \\
\text { fertilizer consumed annually [17] }\end{array}$ & - & - & - \\
\hline & $\begin{array}{l}\text { The value of } \text { Frac }_{\text {GASF, }}, T, N_{(T)} \\
\text { Nex(T), and Frac } \\
\text { as in Table 1. }\end{array}$ & - & - & - & - \\
\hline & $\begin{array}{l}\mathrm{EF}_{4}\left[\mathrm{~kg} \mathrm{~N}_{2} \mathrm{O}-\mathrm{N} \mathrm{kg}^{-1} \mathrm{NH}_{4}-\mathrm{N} \text { and }\right. \\
\mathrm{NO}_{x}-\mathrm{N} \text { deposited] }\end{array}$ & $\begin{array}{l}\text { Emission factor for } \mathrm{N}_{2} \mathrm{O} \text { emission } \\
\text { from atmospheric } \mathrm{NH}_{3} \text { and } \mathrm{NOx}\end{array}$ & $0.01[19]$ & $0.005[8]$ & - \\
\hline \multirow{9}{*}{$\begin{array}{l}\mathrm{N}_{2} \mathrm{O}_{(\mathrm{L})}\left(\mathrm{N}_{2} \mathrm{O} \text { produced from }\right. \\
\text { leaching and runoff of applied } \\
\text { nitrogen fertilizer and animal } \\
\text { manure) }\end{array}$} & $\mathrm{N}_{\mathrm{FERT}}$ & $\begin{array}{l}\text { The total amount of synthetic } \\
\text { fertilizer consumed annually [17] }\end{array}$ & - & - & - \\
\hline & $\begin{array}{l}\text { The value of } \mathrm{T}, \mathrm{N}_{(\mathrm{T})} \text {, and } \mathrm{Nex}_{(\mathrm{T})} \\
\text { are same as in table } 1 .\end{array}$ & - & - & - & - \\
\hline & FraC $_{\text {FUEL-AM }}$ & Animal manure burnt for fuel & $52.5 \%[22]$ & $52.5 \%[22]$ & $\begin{array}{l}\text { IPCC manual suggests using official } \\
\text { statistics of the nation or expert } \\
\text { survey [19]. }\end{array}$ \\
\hline & Frac PRP-AM & $\begin{array}{l}\text { Fraction of animal manure that is } \\
\text { deposited on to the soil by grazing } \\
\text { animal }\end{array}$ & Not used in this study & Not used in this study & No data available. \\
\hline & $\underline{\text { Fraccollec }}$ & Loss during the collection of dung & $30.0 \%[23]$ & $30.0 \%[23]$ & - \\
\hline & $\mathrm{FraC}_{\mathrm{FEED}-\mathrm{AM}}$ & $\begin{array}{l}\text { Fraction of animal manure used } \\
\text { as feed }\end{array}$ & $0.0 \%$ & $0.0 \%$ & $\begin{array}{l}\text { Taken as zero, as animal manure } \\
\text { is hardly used as feed in India [8]. }\end{array}$ \\
\hline & Frac CONST-AM & $\begin{array}{l}\text { Fraction of animal manure used in } \\
\text { construction }\end{array}$ & $2.0 \%[22]$ & $2.0 \%[22]$ & $\begin{array}{l}\text { IPCC manual suggestsuse of } \\
\text { official statistics of the nation or } \\
\text { expert survey [19]. }\end{array}$ \\
\hline & Frac ${ }_{L E A C H}$ & $\begin{array}{l}\text { Fraction of nitrogen lost through } \\
\text { leaching }\end{array}$ & $30.0 \%[19]$ & $10.0 \%[8]$ & $\begin{array}{l}\text { IPCC manual uses default value } \\
\text { of } 30 \% \text { for Frac }{ }_{\text {LEACH. This default }} \\
\text { value was largely based on mass } \\
\text { balance studies comparing } \\
\text { agricultural } N \text { inputs to } N \text { recovered } \\
\text { in rivers. The IPCC manualsuggests } \\
\text { the } N \text { that is deposited away from } \\
\text { agricultural land, a lower value of } \\
\text { Frac }{ }_{\text {LEACH }} \text { may be more appropriate } \\
\text { based on regional or national } \\
\text { studies [19]. Bhatia et al. [8] used } \\
\text { an Indian emission factor of } 10 \% \\
\text { based on the studies by Singh et al. } \\
\text { [30] and Patel et al. [31]. }\end{array}$ \\
\hline & $\begin{array}{l}\mathrm{EF}_{5}\left[\mathrm{~kg} \mathrm{~N}_{2} \mathrm{O}-\mathrm{N} \mathrm{kg}^{-1} \text { leached and }\right. \\
\text { run off }]\end{array}$ & $\begin{array}{l}\text { The emission factor for depositing } \\
\mathrm{N} \text { from leaching and run-off. }\end{array}$ & $0.025[19]$ & $0.005[8]$ & - \\
\hline
\end{tabular}




\section{Nitrous oxide}

The district-wise emission inventory of $\mathrm{N}_{2} \mathrm{O}$ from Assam was based on the formula given by the 1996 revised IPCC guideline [19]. It includes $\mathrm{N}_{2} \mathrm{O}$ emitted as a result of the anthropogenic $\mathrm{N}$-fertilizer input through the direct pathway of nitrification and denitrification from soil and also through indirect pathways, that include volatilisation losses, leaching and runoff from applied $\mathrm{N}$-fertilizer, animal manure etcetera. Thus, the emission of $\mathrm{N}_{2} \mathrm{O}$ was calculated in two steps, namely, direct $\mathrm{N}_{2} \mathrm{O}$ emission from agricultural soil (net sown area) and indirect $\mathrm{N}_{2} \mathrm{O}$ emission from agricultural soil (net sown area) as follows:

$$
N_{2} O_{\text {Total }}=N_{2} O_{\text {direct }}-N+N_{2} O_{\text {Indirect }-} N
$$

\section{Direct $\mathrm{N}_{2} \mathrm{O}$ emission}

The following equation (2.1) was used to estimate the direct emission of $\mathrm{N}_{2} \mathrm{O}$ from the agricultural field (for details about IPCC and Indian factors used in this study see Table 1).

$$
\begin{aligned}
N_{2} O_{\text {direct }}-N= & \left\{\left(F_{S N}+F_{A M}+F_{B N}+F_{C R}\right) * E F_{1}\right\} \\
& +\left(F_{O S} * E F_{2}\right)
\end{aligned}
$$

where $\mathrm{EF}_{1}$ is percentage $\mathrm{N}_{2} \mathrm{O}$ emission from the applied fertilizer, $F_{O S}$ is the area of organic soil harvested, and $\mathrm{EF}_{2}$ is percentage $\mathrm{N}_{2} \mathrm{O}$ emitted from the organic soil.

$\mathrm{F}_{\mathrm{SN}}$ denotes the annual amount of synthetic $\mathrm{N}$ - fertilizer applied to soil, adjusted to account for the amount that volatilizes as $\mathrm{NH}_{3}$ and $\mathrm{NO}_{\mathrm{x}}$ :

$$
F_{S N}=N_{F E R T} *\left(1-\text { Frac }_{G A S F}\right)
$$

where $\mathrm{N}_{\mathrm{FERT}}$ denotes the total amount of synthetic fertilizer consumed annually and Frac $\mathrm{GASF}_{\mathrm{G}}$ is the fraction of fertilizer that volatilizes as $\mathrm{NH}_{3}$ and $\mathrm{NO}_{x}$.

$\mathrm{F}_{\mathrm{AM}}$ denotes the annual amount of animal manure $\mathrm{N}$ applied to soils, adjusted to account for the volatilization as $\mathrm{NH}_{3}$ and $\mathrm{NO}_{\mathrm{x}}$ :

$$
\begin{aligned}
F_{A M}= & \Sigma_{T}\left(N_{T} * N_{e x(T)}\right) *\left(1-\text { Frac }_{G A S M}\right) \\
& *\left[1-\left(\text { Frac }_{F U E L}+\text { Frac }_{P R P}+\text { Frac }_{C O L L E C}\right.\right. \\
& \left.\left.+ \text { Frac }_{\text {FEED }}+\text { Frac }_{C O N S T}\right)\right]
\end{aligned}
$$

where $\mathrm{T}$ stands for each defined livestock category/species (in this study, four categories of livestock, namely, cattle, buffalo, sheep and goat have been taken), $\mathrm{N}_{\mathrm{T}}$ is the number of animals in each category, $\mathrm{N}_{\mathrm{ex}}(\mathrm{T})$ is the annual average nitrogen excretion rate per head for each livestock category, Frac $_{\text {GASM }}$ is the fraction of $\mathrm{N}$ that volatilizes as $\mathrm{NH}_{3}$ and $\mathrm{NO}_{\mathrm{x}}, \mathrm{Frac}_{\mathrm{FUEL}}$ denotes animal

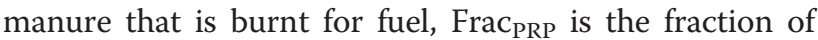
animal manure deposited on soil by grazing livestock, Frac $_{\text {CONST }}$ is the fraction of animal manure used as construction, Frac $\mathrm{FEED}_{\mathrm{FE}}$ is the fraction of animal manure used as feed, Frac- ${ }^{-}$COLLEC is the loss during collection of dung.

$\mathrm{F}_{\mathrm{BN}}$ is the amount of $\mathrm{N}$ - fixed annually by $\mathrm{N}$ - fixing crop as:

$$
F_{B N}=\operatorname{Crop}_{B F} * \operatorname{Frac}_{N C R B F}
$$

where Crop $_{\mathrm{BF}}$ is the seed yield of N-fixing crops. Four crops, that is, gram, arhar, groundnut and soybean were taken into account for the calculation, and Frac $\mathrm{NCRBF}_{\text {is }}$ the $\mathrm{N}$ content of grain and straw of legumes.

$\mathrm{F}_{\mathrm{CR}}$ is the amount of $\mathrm{N}$ in crop residue returned to soil annually:

$$
F_{C R}=\left(\operatorname{Crop}_{S T} * \operatorname{Frac}_{N C R S T}+\operatorname{Crop}_{S B F} * \operatorname{Frac}_{N C R S B F}\right)
$$

Where, Crop $_{\mathrm{ST}}$ is the amount of straw of non-N fixing crops incorporated into soil as residue, Frac $_{\text {NCRST }}$ is the $\mathrm{N}$ content of residue of non- $\mathrm{N}$ fixing crops, Crop $\mathrm{SBF}_{\mathrm{S}}$ is the amount of straw of $\mathrm{N}$-fixing crops incorporated to the soil as residue and Frac $_{\mathrm{NCRSBF}}$ is the $\mathrm{N}$ content of residue of $\mathrm{N}$-fixing crop.

Due to non-availability of data, $F_{B N}$ and $F_{C R}$ are not included in the calculation of $\mathrm{N}_{2} \mathrm{O}-\mathrm{N}$ Direct emission (see Table 1 for details and a note on its potential contribution to the emission inventory for $\mathrm{N}_{2} \mathrm{O}$ ).

\section{Indirect $\mathrm{N}_{2} \mathrm{O}$ emission}

The following equation (2.2) was used for the calculation of indirect emission of $\mathrm{N}_{2} \mathrm{O} \quad\left(\mathrm{N}_{2} \mathrm{O}_{\text {indirect }}\right)$ from the agricultural fields as per the IPCC guideline (for details about IPCC and Indian factors used, see Table 2):

$$
N_{2} O_{\text {Indirect }}=N_{2} \mathrm{O}_{(G)}+N_{2} \mathrm{O}_{(L)}
$$

where $\mathrm{N}_{2} \mathrm{O}$ (G) is the $\mathrm{N}_{2} \mathrm{O}$ produced from volatilization of applied $\mathrm{N}$-fertilizer and animal manure and its subsequent atmospheric deposition as $\mathrm{NO}_{\mathrm{x}}$ and $\mathrm{NH}_{4}$. This is calculated by the formula (2.2.1) as below:

$$
\begin{aligned}
N_{2} O_{(G)}= & {\left[\left(N_{F E R T} * \operatorname{Frac}_{G A S F}\right)+\left(\Sigma _ { T } \left(N_{(T)} * N_{e x(T)}\right.\right.\right.} \\
& \left.\left.* \operatorname{Frac}_{G A S M}\right)\right] * E F_{4}
\end{aligned}
$$

where, $\mathrm{N}_{\mathrm{FERT}}$ is the amount of fertilizer consumed annually, Frac $_{\mathrm{GASF}}$ is the fraction of fertilizer that volatilizes as $\mathrm{NH}_{3}$ and $\mathrm{NO}_{\mathrm{x}}, \sum_{T}\left(N_{(T)} * \mathrm{~N}_{\mathrm{ex}}(T)\right.$ is the amount of $\mathrm{N}$ in animal manure excreted annually, $\mathrm{T}$ is each defined livestock category, $\mathrm{N}_{\mathrm{T}}$ is the number of animals in each category, $\mathrm{N}_{\mathrm{ex}(T)}$ is the annual $\mathrm{N}$ excretion rate per head for each livestock category and $\mathrm{EF}_{4}$ is the emission factor for $\mathrm{N}_{2} \mathrm{O}$ emission from atmospheric $\mathrm{NH}_{3}$ and $\mathrm{NO}_{\mathrm{x}}$. 
Table 3 Details of livestock categories and characteristic [21] used to calculate the nitrogen excretion rate per head $\left(\mathrm{N}_{\mathrm{ex}(\mathrm{T})}\right)$

\begin{tabular}{lllll}
\hline Livestock characteristics & Livestock category & & Sheep & Goat \\
\cline { 2 - 5 } & Cattle & Buffalo & 1.430 & \\
\hline Wet dung excreted by cattle (kg per day) & 8.335 & 10.380 & 50 to 60 & 0.625 \\
\hline Body weight (kg) & 350 & 350 & 0.950 & 30 \\
\hline Urine ( litres per day) & 12.960 & 6.810 & 32 & 0.498 \\
\hline Dry matter content(\%) & 18 & 18 & 1.87 & 32 \\
\hline Nitrogen content (oven-dry,\%) & 1 & 1 & 1.87 \\
\hline
\end{tabular}

$\mathrm{N}_{2} \mathrm{O}$ (L) is $\mathrm{N}_{2} \mathrm{O}$ produced from leaching and the runoff of the applied fertilizer and animal manure and calculated through the following formula (2.2.2):

$$
\begin{aligned}
N_{2} O_{(L)}= & {\left[N_{F E R T}+\left\{\Sigma _ { T } \left(N_{(T)} * N_{e x(T)}\right.\right.\right.} \\
& *\left[1-\text { Frac }_{F U E L-A M}+\text { Frac }_{P R P-A M}\right. \\
& \left.\left.\left.\left.+ \text { Frac }_{C O L L E C}+\text { Frac }_{F E E D-A M}+\operatorname{Frac}_{C O N S T-M}\right)\right]\right\}\right] \\
& * \text { Frac }_{L E A C H} * E F_{5}
\end{aligned}
$$

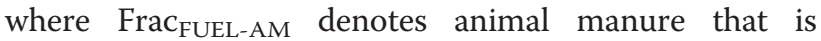
burnt for fuel, Frac PRP-AM is the fraction of animal manure that is deposited onto the soil by grazing live-

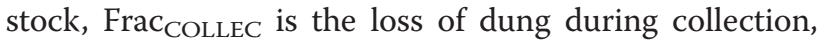

Frac $_{\text {FEED-AM }}$ is the fraction of animal manure that is

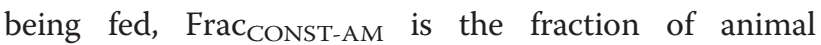
manure that is used as construction, Frac $_{\mathrm{LEACH}}$ is the fraction of N-lost through leaching and $\mathrm{EF}_{5}$ is the emission factor for deposited $\mathrm{N}$ from leaching and runoff.

The IPCC and Indian standard emission factor values were used to calculate the emission of $\mathrm{N}_{2} \mathrm{O}-\mathrm{N}_{\text {Total }}$ for Assam (see Table 1 and 2 for details). For the calculation of $\mathrm{N}_{\text {ext(T) }}$ (in the $\mathrm{F}_{\mathrm{AM}}$ ), the annual average nitrogen excretion rate per head for each livestock category was calculated. The livestock categories used were cattle, buffalo, sheep and goat (see Table 3 for details). The values of annual average nitrogen excretion rate per head $\left(\mathrm{N}_{\text {ext(T) }}\right)$ for each livestock category was the same

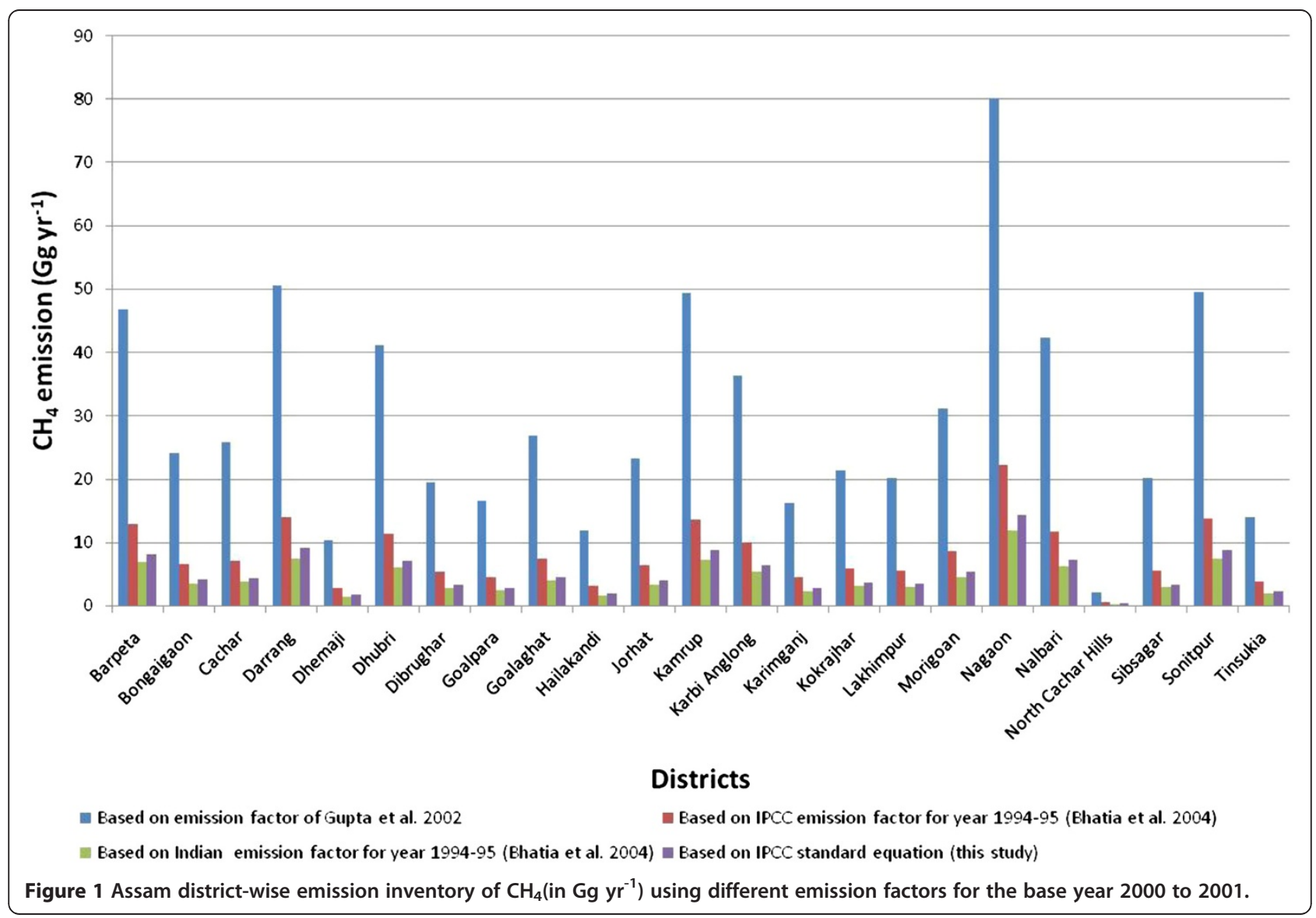


when calculating the $\mathrm{N}_{2} \mathrm{O}$ emission as per IPCC and the Indian standard, since the IPCC guideline suggests using national or expert studies as the reference [19].

\section{Results and discussion}

\section{Methane}

The district wise emission of $\mathrm{CH}_{4}$ from the rice paddy fields of Assam (as per the IPCC standard formula) was estimated to be $121 \mathrm{Gg}$ for the base year 2000 to 2001. Nagaon district emitted the highest amount of $\mathrm{CH}_{4}(14 \mathrm{Gg})$, followed by Darrang (9 Gg) and Sonitpur (8 Gg). The lowest amount of $\mathrm{CH}_{4}$ emission was from the North-Cachar Hills district (0.47), which had lowest area under paddy cultivation. The $\mathrm{CH}_{4}$ emission inventory of Assam State estimated from this study was compared with emission values obtained using three other emission factors (see Figure 1). $\mathrm{CH}_{4}$ emission was highest $\left(682 \mathrm{Gg}\right.$ ) based on the $46 \mathrm{~g} \mathrm{~m}^{-2}$ emission factor of Gupta et al. [33], followed by an emission of $190 \mathrm{Gg}$ based on the $12.81 \mathrm{~g} \mathrm{~m}^{-2}$ emission factor of Bhatia et al. [8], based on IPCC coefficients. The $\mathrm{CH}_{4}$ emission of $102 \mathrm{Gg}$ was lowest when the $6.92 \mathrm{~g} \mathrm{~m}^{-2}$ emission factor of Bhatia et al. [8] was used, which was based on the
Indian emission factors. The $\mathrm{CH}_{4}$ emission estimate based on our study comes out about $121 \mathrm{Gg}$ for the base year 2000 to 2001 .

It is interesting to note that while most of central plain districts of Assam along the banks of Brahmaputra had $\mathrm{CH}_{4}$ emission in the range of 5 to $15 \mathrm{Gg}$, Nagaon district produced a much higher amount of $\mathrm{CH}_{4}$ (see Figure 2). Nagaon district had a greaterarea under rice and also produced more rice in comparison to other central plain districts and thus the higher $\mathrm{CH}_{4}$ emission estimation is very much in line with the anticipated results. It is a matter of concern for scientists, policy makers and planners when there is great difference between the highest $(682 \mathrm{Gg})$ and lowest $(102 \mathrm{Gg})$ values of $\mathrm{CH}_{4}$ emission for a state. Discrepancies of such nature call for an immediate inventory of GHGs at local level for better mitigation planning in future. This variability calls for further strengthening of methodologies in the emission inventory of $\mathrm{CH}_{4}$ from paddy fields at the micro level, to obtain better estimates.

Correlation analysis was carried out between $\mathrm{N}$ fertilizer application and $\mathrm{CH}_{4}$ emission values obtained using the Indian emission factor for the base year

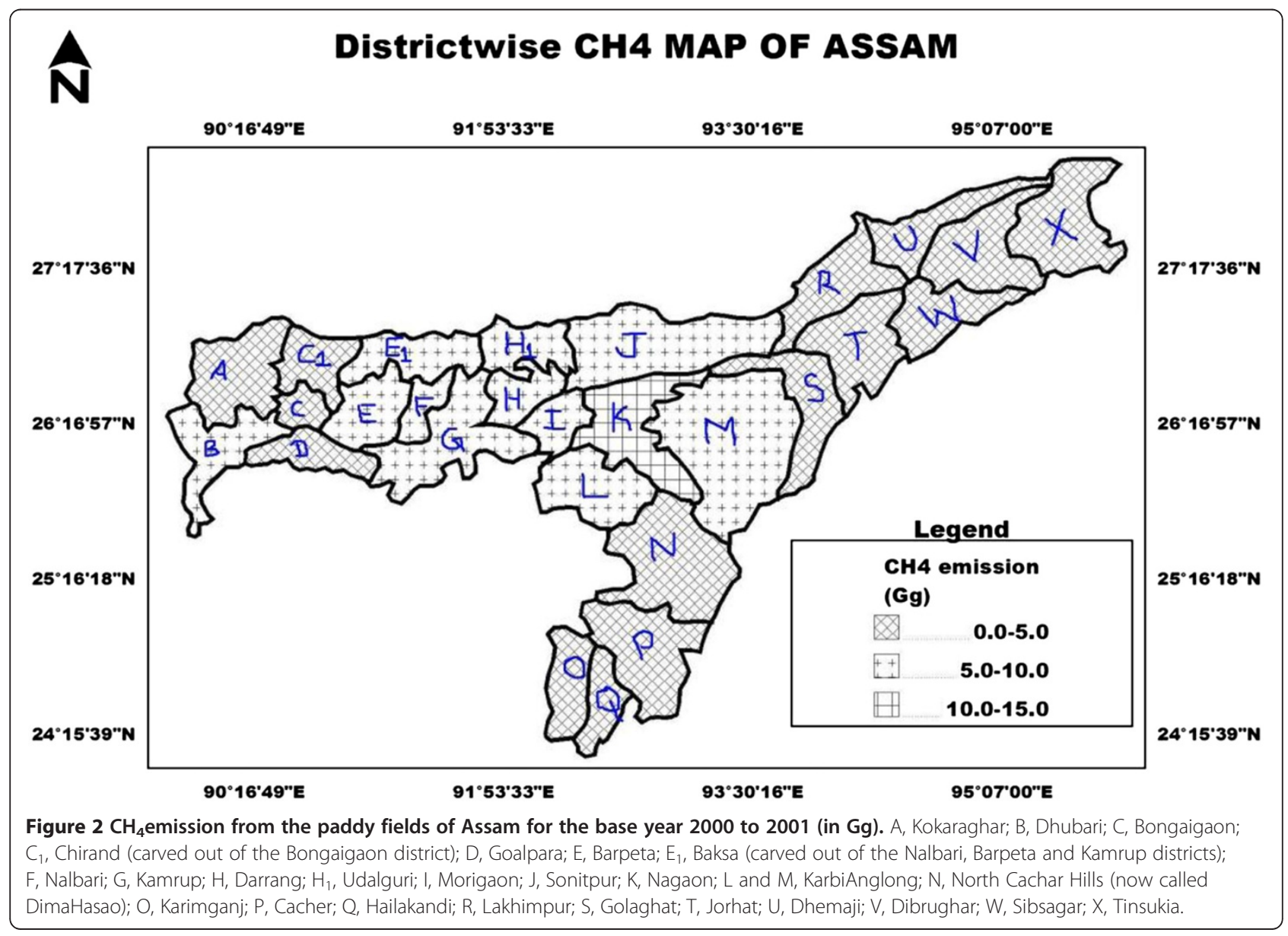


2000 to 2001. A significant relationship $(r=0.84)$ was observed with $95 \%$ confidence. However, this correlation needs to be field-tested in Indian conditions, as there are contradicting claims about nitrogen fertilizer application and its impact on increasing [34] or decreasing [35] the $\mathrm{CH}_{4}$ emission from paddy fields.

\section{Nitrous oxide}

Emission of $\mathrm{N}_{2} \mathrm{O}-\mathrm{N}$ using the IPCC standard was estimated at $1.36 \mathrm{Gg}$ for the base year 2001 to 2002, while the emission estimated using the Indian standard was $0.43 \mathrm{Gg}$ (Figure 3). This difference of about $216 \%$ between the lowest and highest values of the $\mathrm{N}_{2} \mathrm{O}$ emission inventory was due to the different emission factors of the IPCC and the Indian standards used for the calculation of direct and indirect $\mathrm{N}_{2} \mathrm{O}$ emission (see Table 1 and 2 for details). This variation in $\mathrm{N}_{2} \mathrm{O}$ emission emphasises the need for micro-level planning for future data gathering and inventory management to have an accurate and dependable database of GHG emissions from agricultural fields. This may lead to better agriculture management and mitigation planning in future. For $\mathrm{N}_{2} \mathrm{O}$ also, the central plain districts of Assam emissions were much higher than for rest of the state $(0.04 \mathrm{Gg}$ to $0.18 \mathrm{Gg}$; see Figure 4). Unlike $\mathrm{CH}_{4}$, in the case of $\mathrm{N}_{2} \mathrm{O}$, the different ranges of emission are widely spread over the state.
Correlation analysis was performed to find out the relationships between the $\mathrm{N}_{2} \mathrm{O}$ emissions and application of $\mathrm{N}$-fertilizer. Correlation analysis was carried out for the emission values obtained from the IPCC and Indian standard for the year 2001 to 2002. It was found that there is a significant correlation $(r=0.98$ at $95 \%$ confidence level) between $\mathrm{N}_{2} \mathrm{O}$ emission (Indian standard) with that of $\mathrm{N}$-fertilizer used in that year. Similar strong correlation ( $r=0.98$ at $95 \%$ confidence level) was found between $\mathrm{N}_{2} \mathrm{O}$ emission (using an IPCC emission factor) and $\mathrm{N}$-fertilizer used in that base year. These significant correlations reinstate the earlier findings that $\mathrm{N}$-fertilizers are the major sources of $\mathrm{N}_{2} \mathrm{O}$ emitted from agricultural soils.

\section{Conclusions}

District-wise emission of $\mathrm{CH}_{4}$ (for the base year 2000 to 2001) from the paddy fields of Assam is estimated to be $121 \mathrm{Gg}$ based on this study. However, there is a large difference in the highest $(682 \mathrm{Gg}$ ) and lowest (102 Gg) value of $\mathrm{CH}_{4}$ emission when different emission factors were used. The district-wise $\mathrm{N}_{2} \mathrm{O}$ emission (for the base year 2001 to 2002) for Assam State was estimated to be $1.36 \mathrm{Gg}$ and $0.43 \mathrm{Gg}$ using the IPCC and Indian factors respectively.

The study clearly shows that there is large variation in the emission inventory of $\mathrm{CH}_{4}$ and $\mathrm{N}_{2} \mathrm{O}$ at the district level when different emission factors are used. This

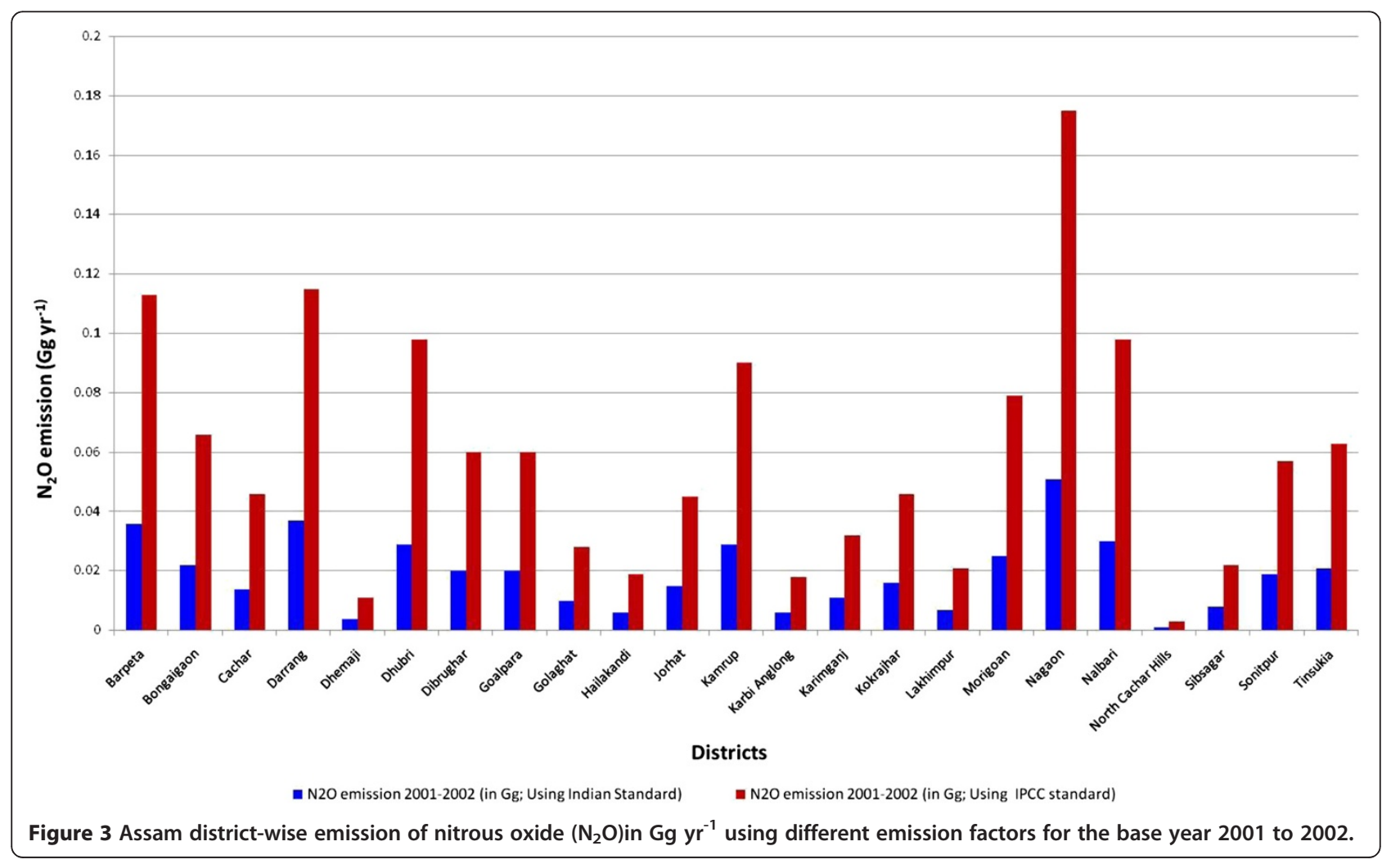




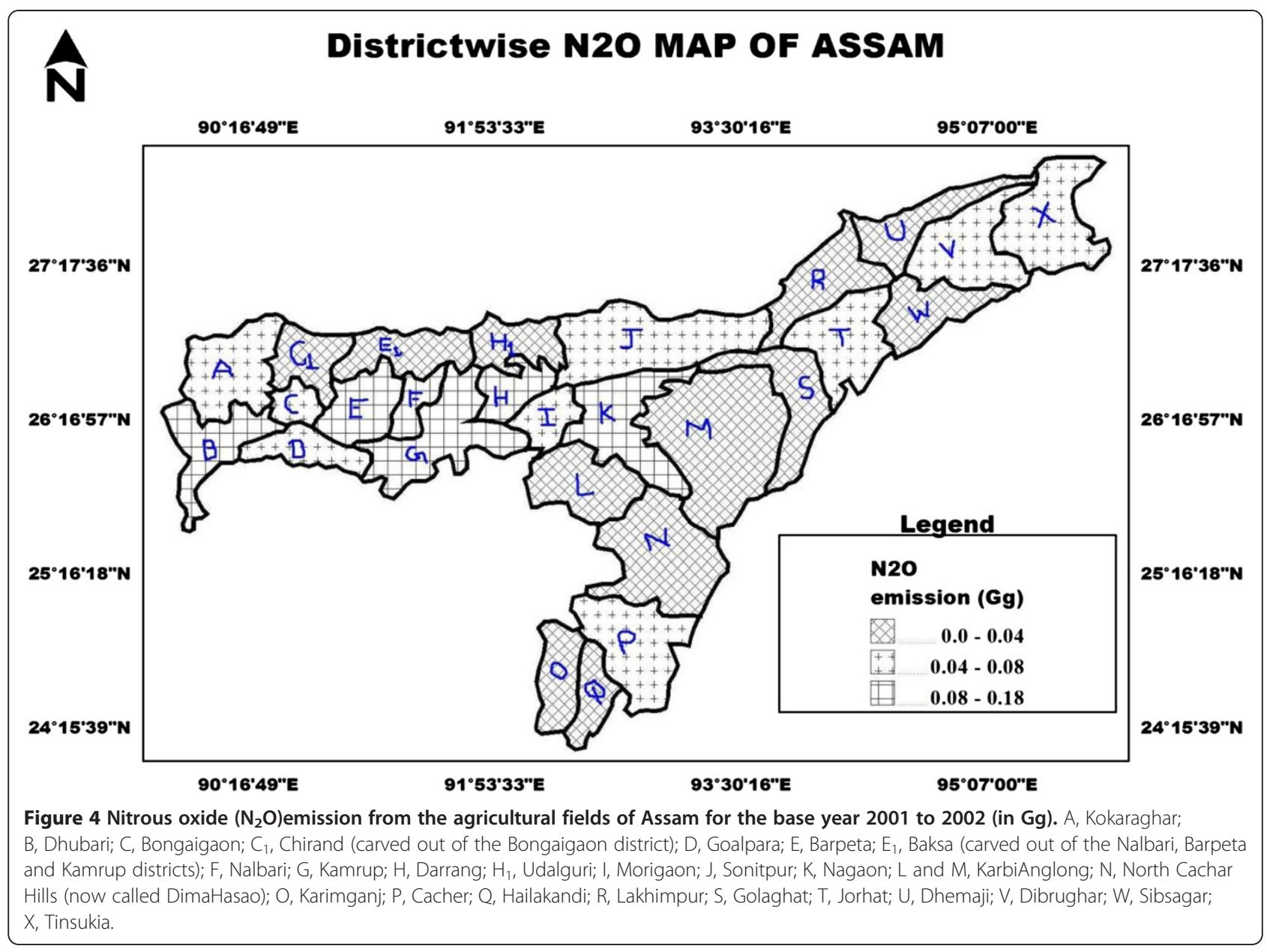

indicates that for an accurate inventory of $\mathrm{CH}_{4}$ and $\mathrm{N}_{2} \mathrm{O}$, universal or regional emission factors cannot be applied at the smaller scale (for example,at district level). The emission of $\mathrm{CH}_{4}$ and $\mathrm{N}_{2} \mathrm{O}$ from the agricultural sector is a function of specific crop and site, and is influenced by factors such as cultural practice, agronomic management, soil type and socio-economic drivers. This calls for detailed and comprehensive mapping and data collection at the micro-level for accurate inventory of $\mathrm{CH}_{4}$ and $\mathrm{N}_{2} \mathrm{O}$ in the future. This is pertinent in the present context when more emphasis is being given to the localisation of issues to avert the negative effect of climate change, and the bottom-up approach to planning. In the Indian context, this is even more important as power and planning are being devolved more at the bottom-most level of governance, namely, the Panchayats and District Planning Committee as per the Indian Constitution (article 243ZD[3-a] ) on the issue of environmental planning and conservation [36]. So, it is important to have strong and able local-level planning to mitigate the $\mathrm{CH}_{4}$ and $\mathrm{N}_{2} \mathrm{O}$ emission in the future, on the basis of sound estimates of these gases. This requires little extra effort from various stakeholders to raise the level of awareness among researchers, policy makers and farmers by providing them adequate training and sensitisation to local issues.

\section{Endnotes}

${ }^{\mathrm{a}}$ Non-annex countries are a group of 152 countries classified by the IPCC, belonging to the low-income group, with very few classified as a middle-income group. For detail see <http://unfccc.int/parties_and_ observers/parties/non_annex_i/items/2833.php >.

${ }^{\mathrm{b}}$ Since 1950, the area under cultivation in India had increased by only 27.43 times (96.6 million hectares in 1951 to 1952 to 123.1 million hectares in 1999 to 2000), while the application of $\mathrm{N}$-fertilizer $(55,000$ tonnes in 1950 to 1951 to $11,592,500$ tonnes in 1999 to 2000) increased by about 20,977 times $[18,37,38]$. This increasing use of $\mathrm{N}$-fertilizer on the limited land is not only posing a threat in term of $\mathrm{N}_{2} \mathrm{O}$ emission causing global warming but also reducing $\mathrm{N}$-use efficiency of the plant.

${ }^{c}$ The emission of $\mathrm{CH}_{4}$ and $\mathrm{N}_{2} \mathrm{O}$ was calculated for different base years, namely, 2000 to 2001 and 2001 to 2002 respectively. This was due to the availability of relevant data for the calculations. 
${ }^{\mathrm{d}}$ When the study was carried out in 2004, the data were available only for 23 districts of Assam state. In 2012, Assam has total of 27 districts. For this study we have done the calculation for 23 districts. While representing the emission on the GIS map we mentioned the name of the new districts and also the name of the parent district from which the new district was carved out.

${ }^{\mathrm{e}}$ In the year 2000 to 2001, of the total gross cropped area of 38.43 lakh hectares in Assam, about 26.46 lakh hectares was under paddy (autumn, winter and summer paddy cultivation) cultivation $[24,39]$.

\section{Abbreviations}

CFCs: Chlorofluorocarbon; $\mathrm{CH}_{4}$ : Methane; $\mathrm{CO}_{2}$ : Carbon dioxide; GDP: Gross domestic product; Gg: Gigagram; GHG: Greenhouse gas; GIS: Geographic information systems; Gol: Government of India; GWP: Global warming potential; HYV: High yielding variety; IPCC: Intergovernmental Panel on Climate Change; $\mathrm{N}_{2} \mathrm{O}$ : Nitrous oxide; Tg: Terragram.

\section{Competing interests}

The authors declare that they have no competing interests.

\section{Authors' contributions}

SNM and SM conceived the idea of study and participated in its initia design, data collection, data analysis, and initial drafting of the research work. $L R, S D$ and PS participated in further data analysis and drafting the final manuscript. All authors read and approved the final manuscript.

\section{Author details}

'Institute of Rural Management, Post Box No. 60, Anand 388001 Gujarat, India. ${ }^{2}$ School of Environmental Sciences, Jawaharlal Nehru University, New Delhi

110067, India. ${ }^{3}$ Indian Institute of Technology-Guwahati, Assam 781039, India.

Received: 10 April 2012 Accepted: 19 September 2012

Published: 5 October 2012

\section{References}

1. Metz B, Davidson OR, Bosch PR, Dave R, Meyer LA: (Eds): Climate change contribution of working group III to the fourth assessment report of the intergovernmental panel on climate change. Cambridge: Cambridge University Press; 2007.

2. Watson RT, Zinyowera MC, Moss RH: Climate change 1995-impacts, adaptations and mitigation of climate change. Scientific-technical analyses. In Contribution of working group II to the second assessment report of the Intergovernmental Panel on Climate Change. Cambridge: Cambridge University Press; 1996:289-324.

3. Battle M, Bender M, Sowers T, Tans PP, Butler JH, Elkins JW, Ellis JT, Conway T, Zhang N, Lang P, Clarke AD: Atmospheric gas concentrations over the past 20 century measured in air from firn at the south pole. Nature 1996, 383:231-235.

4. United States Environmental Protection Agency (USEPA): Global Anthropogenic Non-CO Greenhouse Gas Emissions: 1990-2020. Washington DC: 2006. http://www.epa.gov/nonco2/econ-inv/downloads/ GlobalAnthroEmissionsReport.pdf.

5. Huang $Y$, Wang $H$, Huang H, Feng ZW, Yang ZH, Luo YC: Characteristic of methane emission from wetland rice-duck complex ecosystem. Agriculture, Ecosystems and Environment 2005, 105:181-193.

6. Ahrens TD, Beman JM, Harrison JA, Jewett PK, Matson PA: A synthesis of nitrogen transformations and transfers from land to the sea in the Yaqui Valley agricultural region of northwest Mexico. Water Resources Research 2008, 44:W00A05. doi:10.1029/2007WR006661.

7. Government of India: Interim report of the expert group on low carbon strategies for inclusive growth. New Delhi: 2011.

8. Bhatia A, Pathak H, Aggrawal PK: Inventory of methane and nitrous oxide emission from agricultural soils of India and their global warming potential. Current Science 2004, 87:317-324.

9. Sinha SK: Global methane emission from rice paddies: excellent methodology but poor extrapolation. Current Science 1995, 68:643-646
10. Parashar, et al: Methane budget from paddy fields in India. Chemosphere 1996, 33:737-757.

11. Jain MC, Kumar S, Wassmann R, Mitra S, Jain MC, Singh SD, Singh JP, Singh $R$, Yadav AK, Gupta S: Methane emissions from irrigated rice fields in northern India (New Delhi). Nutrient Cycling in Agroecosystems 2000, 58:75-83.

12. Khosa MK, Sidhu BS, Benbi DK: Methane emission from rice fields in relation to management of irrigation water. Journal of Environmental Biology 2011, 32:169-172

13. Government of India (Gol): National Action Plan on Climate Change. New Delhi: 2008

14. Sharma SK, Choudhury A, Sarkar P, Biswas S, Singh A, Dadhich PK, Singh AK, Majumdar S, Bhatia A, Mohini M, Kumar R, Jha CS, Murthy MSR, Ravindranath NH, Bhattacharya JK, Karthik M, Bhattacharya S, Chauhan R: Greenhouse gas inventory estimates for India. Current Science 2011, 101:405-415.

15. Ghosh S, Majumdar D, Jain MC: Methane and nitrous oxide emissions from irrigated rice of North India. Chemosphere 2003, 51:181-195.

16. Gogoi B, Baruah KK: Nitrous oxide emission from tea (Camellia sinensis (L.) O. kuntze)- planted soils of North East India and soil parameters associated with the emission. Current Science 2011, 101:531-535.

17. Government of Assam (GoA): Statistical Handbook-Assam, Directorate of Economics and statistics. Guwahati: 2003.

18. Centre for Monitoring Indian Economy (CMIE): Agriculture Production in India - State wise and Crop wise data. Mumbai: 1988:19-26.

19. Inter-Governmental Panel on Climate Change (IPCC): Good Practice Guidance and Uncertainty Management in National Greenhouse Gas Inventories. New York: Cambridge University Press; 1996.

20. Sarkar MC, Banerjee NK, Rana DS, Uppal KS: Field measurements of ammonia volatilization losses of $\mathrm{N}$ from Urea applied to wheat. Fertilizer News 1991, 36:25-29.

21. Gaur AC, Neelakanthan S, Dargan KS: Organic Manures. New Delhi: Indian Agriculture Research Institute; 1984

22. Tandon HLS: Fertilizer, Organic manures, Recyclable wastes and Biofertilizers. New Delhi: FDCO; 1992.

23. TERI: The Energy Research Institute: Energy Data Directory and year Book 2000-01. New Delhi: TERI Press.

24. Assam Small Farmers' Agri-Business Consortium: Assam agriculture at glance. Guwahati: 2005. http://assamagribusiness.nic.in/ASAGRI.pdf.

25. Kumar U, Jain MC, Kumar S, Pathak H, Majumdar D: Effects of moisture levels and nitrification inhibitors on $\mathrm{N}_{2} \mathrm{O}$ emission from a fertilized clay loam soil. Current Science 2000, 79:224-228.

26. Pathak H, Bhatia A, Prasad S, Jain MC, Kumar S, Singh S, Kumar U: Emission of nitrous oxide from soil in rice-wheat systems of Indo-Gangetic plains of India. Environ. Monit. Assess 2002, 77:163-178.

27. Clayton H, McTaggart IP, Parker J, Swan L, Smith KA: Nitrous oxide emissions from fertilised grassland: a 2-year study of the effects of fertiliser form and environmental conditions. Biology and Fertility of Soils 1997, 25:252-260.

28. Klemedtsson L, Klemedtsson AK, Escala M, Kulmala A: Inventory of $\mathrm{N}_{2} \mathrm{O}$ emission from farmed European peatlands. In Approaches to Greenhouse Gas Inventories of Biogenic Sources in Agriculture. Edited by Freibauer A Kaltschmitt M. Lökeberg: Sweden: Proceedings of the Workshop at Lökeberg: 1998:79-91.

29. Majumdar D, Kumar S, Pathak H, Jain MC, Kumar U: Reducing nitrous oxide emission from rice field with nitrification inhibitors. Agric. Ecosyst. Environ 2000, 81:163-169.

30. Singh B, Singh Y, Khind CS, Meelu OP: Leaching losses of urea-N applied to permeable soils under different hydrological situations. Fertilizer Research 1991, 28:179-184

31. Patel SK, Pamda B, Mohanty SK: Relative ammonia loss from urea based fertilizers applied to rice under different hydrological situations. Fertilizer Research 1989, 19:113-119.

32. Bhattacharya S, Gupta PK, Parashar DC: Greenhouse gas emission in India: methane budget estimates from rice fields based on data available upto 1995 Centre for Global Change, National Physical Laboratory, Scientific Report No. 21; 1996

33. Gupta PK, Sharma C, Mitra AP: Methane measurements from rice fields in India. New Delhi: Centre on Global Change, National Physical Laboratory; 2002.

34. Lindau C, Bollich P, Delaune R, Patrick W, Law V: Effect of urea fertilizer and environmental factors on methane emission from a Louisiana USA rice field. Plant Soil 1991, 136: 195-203. 
35. Zou J, Huang Y, Jiang J, Zheng X, Sass RL: A 3-year field measurement of methane and nitrous oxide emissions from rice paddies in China: effects of water regime, crop residue, and fertilizer application. Global Biogeochem. Cycles 2005, 19GB2021. doi:10.1029/2004GB002401.

36. Kashyap SC: Our constitution - an introduction to India' constitution and constitutional law. New Delhi: National Book Trust; 2001.

37. Centre for Monitoring Indian Economy (CMIE): Agriculture. Mumbai; 2004.

38. The Fertilizer Association of India (FAl): Fertilizer Statistics. New Delhi; 2000.

39. Barah $B C$, Betne R, Bhowmick BC: Status of rice production system in Assam: a research perspective. In Prioritization of strategies for agriculture development in north-eastern India: October 2001; New Delhi. Edited by Barah BC. New Delhi: National centre for Agriculture Economics and Policy Research; October 2001:50-68.

doi:10.1186/2048-7010-1-16

Cite this article as: Mishra et al:: Exploration of 'hot-spots' of methane and nitrous oxide emission from the agriculture fields of Assam, India. Agriculture \& Food Security 2012 1:16.

\section{Submit your next manuscript to BioMed Central and take full advantage of:}

- Convenient online submission

- Thorough peer review

- No space constraints or color figure charges

- Immediate publication on acceptance

- Inclusion in PubMed, CAS, Scopus and Google Scholar

- Research which is freely available for redistribution 